\title{
SOCS1 Gene
}

National Cancer Institute

\section{Source}

National Cancer Institute. SOCS1 Gene. NCI Thesaurus. Code C97794.

This gene is involved in the attenuation of cytokine signaling. 